\title{
Information Sharing, Bank Penetration and Tax Evasion in Emerging Markets
}

\author{
Duc Hong Vo ${ }^{1}\left(\mathbb{D}\right.$, Ha Minh Nguyen ${ }^{1}{ }^{\mathbb{D}}$, Tan Manh Vo $^{2}$ and Michael McAleer ${ }^{3,4,5,6,7, * \mathbb{C}}$ \\ 1 Business and Economics Research Group, Ho Chi Minh City Open University, Ho Chi Minh City 700000, \\ Vietnam; duc.vhong@ou.edu.vn (D.H.V.); ha.nm@ou.edu.vn (H.M.N.) \\ 2 Vietnam-The Netherlands Program, Ho Chi Minh City 700000, Vietnam; tan.vn@vnp.edu.vn \\ 3 Department of Finance, Asia University, Taichung 41354, Taiwan \\ 4 Discipline of Business Analytics, University of Sydney Business School, Sysney NSW 2006, Australia \\ 5 Econometric Institute, Erasmus School of Economics, Erasmus University Rotterdam, 3062 PA Rotterdam, \\ The Netherlands \\ 6 Department of Economic Analysis and ICAE, Complutense University of Madrid, 28040 Madrid, Spain \\ 7 Institute of Advanced Sciences, Yokohama National University, Yokohama 240-8501, Japan \\ * Correspondence: michael.mcaleer@gmail.com
}

Received: 26 December 2019; Accepted: 9 April 2020; Published: 20 April 2020

check for updates

\begin{abstract}
Tax evasion, which is typically considered an illegal activity, is a critical problem and is considered a barrier to economic growth. A review of the literature shows that tax and social security contributions, regulations, public sector services, the quality of institutions and tax compliance, play important roles in determining the degree to which firms attempt to evade taxes. Measuring tax evasion is problematic due to data requirements and inadequacies. Few tax evasion indices have been estimated but it appears that they cannot be used for international comparisons across countries. This important issue has largely been ignored in the literature, in particular for emerging markets. Consequently, this paper is conducted to develop a new tax evasion index (TEI) using the most substantial and recent data from the standardized World Bank Enterprises Survey 2006-2017. In addition, using the newly developed TEI, the paper examines the importance and contribution of information sharing and bank penetration to the degree of tax evasion in emerging markets. The paper uses a sample of 112 emerging markets from 2006-2017 and the Tobit model in estimation. The empirical findings from the paper indicate that the average TEI during the 2006-2017 period for emerging markets is 0.62 , with a range of $(0.25,0.75)$. In addition, we find that information sharing and bank penetration negatively affect the degree of tax evasion, as proxied by the TEI, in emerging markets. The empirical results also confirm the view that large firms are considered to have adopted good tax compliance practices, while firms located in remote areas are more likely to evade taxes. Policy implications have emerged on the basis of the empirical findings from the paper.
\end{abstract}

Keywords: tax evasion; information sharing; bank penetration; firms' size; firms' location; emerging markets

JEL Classification: E26; G14; H26

\section{Introduction}

In emerging markets, tax evasion is a critical problem and is generally considered barriers to economic growth. Existing studies have focused significantly on the linkages between financial development and formal economic activities. This financial development-economic growth nexus has attracted substantial attention in the literature on economic and financial development. However, to date, a limited number of studies on the effects of financial intermediary developments including 
information sharing and bank penetration on the unofficial economic activity or the shadow economy, have been conducted (Rizzi 2017; Ly and Vo 2014). Examining this economic and financial relationship is essential as the shadow economy is a substantial problem in emerging markets.

Johnson et al. (1998) and Friedman et al. (2000) estimated the total contribution of shadow economic activities to GDP to range from 10 to 15 per cent in developed countries and from 19 to 46 per cent in emerging markets. Moreover, the shadow economy can negatively affect economic growth in two main directions. First, it constrains investment opportunities as illegal firms may only operate in an underground environment, which does not provide necessary market-support. Second, the shadow economy leads to tax evasion, which reduces government tax revenues.

As a result of the shadow economy, tax evasion is typically taken to be an illegal activity that is intended to hide taxable income from tax authorities and/or to claim fraudulent expenses in order to reduce tax liabilities. By reporting a smaller income, higher expenses or, in extreme cases, no income at all, firms are able to evade tax. Such enterprises are then faced with the possibility of being caught cheating, so that a monetary fine can be imposed, in addition to payment of the previously evaded tax.

One of the primary reasons for tax evasion arises through information asymmetry because most tax authorities in emerging markets do not have sufficient information to capture illegal activities that are intended to reduce tax liabilities. Financial development, such as information sharing and bank penetration which accelerates information processing and promotes transparent markets, are believed to be capable of controlling the level of tax evasion.

Better information sharing and bank penetration are among the targets of financial intermediary development. Together with other financial factors, including macroeconomic factors, their role is to help: (a) formal banks to increase their loan security by avoiding information asymmetry between loan owners and loan takers; and (b) firms that operate legally in the economy to receive economic benefits. The major factors have been discussed and confirmed in several previous studies, including Love and Mylenko (2003); Beck et al. (2011); Beck et al. (2014); and Vo et al. (2015).

Financial developments, including information sharing and bank penetration, could assist tax evasion relief from various perspectives. Straub (2005) and Beck et al. (2007) suggested that improved access to formal credit services helps increase formal operating firm benefits, which would assist in reducing tax evasion. Moreover, information sharing leads to lower transaction costs and improves credit efficiency by enhancing credit availability (Brown et al. 2009) and reduces bank corruption in lending (Barth et al. 2009; Pham and Vo 2014). Such empirical evidence boosts the benefits to formal firms, thereby lowering the motivation to evade tax of the informal group.

Moreover, tax evasion could appear under the label of "cooking the books." In financial systems where information sharing and bank penetration are well established, firms that misreport their revenues would face greater obstacles in borrowing. Official banks and other financial intermediary institutions would prefer appropriate functioning firms because of lower risks due to lower information asymmetry. They would then be less likely to allocate financial resources to misreporting firms. As such, the opportunity costs of evading tax would be higher in emerging markets that have enhanced information sharing and high levels of bank penetration (Beck et al. 2014; Tran and Vo 2018).

In April 2016, a huge leak of confidential documents regarding taxes, known as the "Panama Papers," revealed significant information about how the rich are able to hide their assets to evade tax under a particular Panamanian law firm by the name of Mossack Fonseca. The consequences spread rapidly around the world, thereby creating a global scandal. This financial shock also raised the serious issue as to how governments really manage and control tax evasion. Emerging markets do not have advanced tax systems with high tax revenues and significant tax coverage. The lack of tax revenues is a major problem as many governments in emerging markets could be deeply in debt, while they are simultaneously seeking to finance national expenditures at all government levels.

A review of the literature shows that tax and social security contributions, regulations, public sector services, the quality of institutions and tax compliance play important unidirectional roles in determining whether firms attempt to evade government taxes. In addition, one of the most significant 
data sources, the standardized data set of the World Bank Enterprise Surveys, does not appear to have been analyzed comprehensively. The contents and structure of the surveys have changed over time, which also lead to missing variables and observations. These issues emphasize the need to investigate alternative measurements of tax evasion that do not suffer from the deficiencies of existing measures and methods. This paper is one of the first of its kind in the literature to attempt this task.

The structure of the paper is as follows. Following this Introduction, Section 2 provides a literature review on tax evasion approaches, information sharing and bank penetration on tax evasion. Constructing the new tax evasion index, including the required data and the final estimates of degree of tax evasion across emerging markets, are discussed and presented in Section 3. Section 4 examines the importance and contribution of information sharing and bank penetration on tax evasion. The section is then extended with the focus on firms size and location. Some concluding remarks and policy implications are discussed in Section 5.

\section{Literature Review}

\subsection{Tax Evasion Approaches}

Numerous attempts have been conducted to verify the validity of the classic tax evasion model of Allingham and Sandmo (1972). Much of the research has concentrated on two parameters that represent enforcement intensity, namely the audit rate and tax rate. However, existing empirical results have failed to establish a viable method to measure the level of tax non-compliance. The extant literature has provided three main approaches to measure tax evasion in emerging markets (for further details, Schneider and Enste 2000), which can be summarized as follows.

First, direct approaches include voluntary surveys, tax auditing and other compliance methods. For example, the U.S. Internal Revenue Services (IRS) implemented a detail audit program from 1965 to 1988 on a stratified random sample of nearly 50,000 individual tax returns every 3 years to detect the tax gap. The result of the audit is used to generate the actual income of an individual. A comparison with reported income from that person presents the tax gap. This measure could be considered as a proxy for tax evasion.

The advantage of the direct approach is the detailed information that can be elicited from replies. However, dishonest answers are considered to be the primary disadvantage of the approach. Data can be distorted or biased depending on the attitudes and willingness of respondents to answer correctly because most of them are hesitant to reveal sensitive information. The quality of this method also depends on how the questionnaire is constructed and implemented.

Second, the indirect approaches, known as indicator approaches, primarily use macroeconomic and other indicators to estimate the growth in tax evasion over time. They examine traces of tax evasion in measurable indicators. Some indicators that have been used to measure unofficial sectors include differences in measurement between the expenditure and income approaches of gross national product (GNP); discrepancies between the official and actual labor force and differences over time between the volume of transactions and official GNP. Another approach is to check transactions that use money, under the assumption that the true level of economic activity could be fully described by a relationship between money and the velocity.

In comparing the estimated level of economic activity and official national accounts, it is possible to determine the "shadow economy," which could be used as a proxy to measure tax evasion. Although all indirect methods could be used to measure tax evasion, with data available from many sources for extended periods, each method has limitations and may not be applicable in each and every case (for further details, see Schneider and Enste (2000)). One of the most important reasons is that all indirect methods use only one indicator to represent the effects of the shadow economy and/or tax evasion. Moreover, some monetary approaches consider only the tax burden as the cause of tax evasion. However, the shadow economy and tax evasion have been established for many reasons and are responsible for many impacts in production, labor and money markets. 
Third, model approaches were introduced by Frey and Weck (1983a, 1983b) and Frey and Weck (1984) when 24 OECD countries were examined to determine the size of the shadow economy. Based on statistical theory, the shadow economy or tax evasion are considered to be unobserved latent variables and could be estimated using a cause-and-effect model, which would be measurable. The Dynamic Multiple Indicators-Multiple Causes (or DYMIMIC) approach seems to fully explain the meaning of the model approach and can be used to demonstrate the advantages of flexibility and precision, among others.

\subsection{Information Sharing and Bank Penetration on Tax Evasion}

Information sharing in financial development indicates the exchange of data between financial organizations with the focuses primarily on credit information. Bank penetration refers to physical outreach by banks and lending institutions. Market transparency and the availability of credit are represented by these two indicators that contribute to financial development. These indicators are associated with the mitigation of tax evasion. There are a number of cases where firms deny their legal corporate tax duties or evade tax. Beck et al. (2014) divide such cases into two main groups:

(i) The first group of firms gains illegal benefits because they are operating in the under-developed emerging markets. As such, they may choose to hide their outputs because the systems cannot detect the activities. This group achieves no tax burden but faces an unsupportive business environment, as well as the possible imposition of tax penalties by governments in emerging markets.

(ii) The second group of firms chooses to be formal but reduces their tax obligations by "cooking the books." Such firms are more difficult to be caught, as incorrect information in their financial statements and general ledgers are not easy to be discovered. Consequently, the decisions from such firms are illegal and the firms face potential punishment.

Theoretical and empirical evidence has been presented to examine the impacts of information sharing and bank penetration on the corporate tax evasion level. Based on financial constraints, Allingham and Sandmo (1972) suggested that a rational individual decides to pay or not pay tax due to the consideration of maximizing the utility. Johnson et al. (2000) noted motivation of firms to hide their incomes in emerging markets because they are unable to exploit the advantages when they are operating in the formal economic sector.

Straub (2005) and Beck et al. (2007) suggested that improving access to formal credit services helps increase the benefits to firms operating in the formal environment. Moreover, information sharing can lead to lower transaction costs and improved credit efficiency by enhancing credit availability (Brown et al. 2009) and reducing bank corruption in lending (Barth et al. 2009). Such evidence boosts the benefits to firms operating in the formal group, thereby lowering any incentives to evade taxes from firms operating in the informal group.

Hidden revenues by "cooking the books" can also be reduced by improving information sharing and bank penetration. Tax evasion using this method causes uncertainty in the financial reports prepared by firms. Consequently, doing so will raise the costs of banks in double checking to avoid potential risks. The additional costs are usually transferred to borrowers as they subsequently face higher interest rates and stricter loan conditions (Graham et al. 2008). In financial systems where information sharing and bank penetration are well established, firms that misreport their revenues are likely to face greater obstacles in borrowing funds.

Formal banks and other financial intermediary institutions prefer doing business with firms operating in the formal sector because of lower risks associated with lower information asymmetry. Consequently, they will be less likely to allocate resources to firms with the history of misreporting revenue or costs. As such, the opportunity costs of tax evasion are higher in emerging markets with enhanced information sharing and high levels of bank penetration (Beck et al. 2014). There are also offsetting effects. Tax evading firms do not report hidden resources in their lists of financial assets. 
However, as firms need to demonstrate collaterals for borrowings, such firms that engage in tax evasion have fewer opportunities to present collaterals for their intended loans.

As a result, stricter lending conditions and higher interest rates could be applied by banks for the borrowing because banks consider riskier to provide loans to firms without good assets which can be used as the collaterals for the borrowings. In the emerging markets with high levels of information sharing and bank penetration, the importance of collaterals is relatively low as lenders can now monitor borrowers because of lower information asymmetry (Beck et al. 2011; Gellard et al. 2013). Firms may benefit when lower collateral is required in order to obtain loans. In short, tax evasion worsens the opportunities for firms in such emerging markets.

Previous empirical studies have emphasized the roles of firm size and location for the tax evasion problem. Beck et al. (2005) found that small firms are more sensitive to the depth of the financial sector in comparison with larger firms. The same pattern arises for firms in smaller cities and towns. Houston et al. (2010) observed that access to formal finance will benefit the group of small firms, as well as firms that depend on external finance and exhibit high growth opportunities, in comparison with larger firms. The authors suggested that information sharing and bank penetration may have different impacts on different groups of firms, according to their size and location. In conclusion, firms with smaller size, externally financial dependence and potentially high growth react strongly to changes in the financial factors in comparison with firms of another opposite groups.

\section{Constructing the Tax Evasion Index}

\subsection{Methodology and Data}

The Ministry of Finance of Ministry of Finance of Bulgaria (2016) mentioned tax evasion as a critical factor through which the shadow economy can be measured. The shadow economy itself establishes the environment in which the informal sector failed to follow tax regulations and correctly report their performances to the authorities. Operating in this environment helps firms to adopt illegal activities including reporting lower revenues to the authorities, false bookkeeping or the sale of undervalued real estate assets.

Legal operations with false bookkeeping and reporting; and illegal firms, which are the two main components of tax evasion, are included in this index. Ela (2013) supported this argument by describing the relationship between the shadow economy and tax evasion as a "feed and strengthen" interaction. Heavy tax burdens increase the tendency for firms to operate in the informal sector.

Schneider and Enste (2000) and Schneider and Buehn (2013), among others, concluded the following six main issues to have an impact on the shadow economy and tax evasion. On this paper, this paper utilizes these issues and combines them into the following five factors which all together lead to the tax evasion index: (i) tax and social security contribution burdens; (ii) regulations; (iii) public sector services; (iv) quality of institutions; and (v) tax compliance.

The World Bank Enterprises Survey satisfies the requirements of variables for the two following reasons. First, the survey is designed for face-to-face interviews with managers, especially managing directors, of companies. Alternative interviewees are head of human resources and accountants, both of whom are directly or indirectly related to the decision-making process with the directors of firms on tax issues and other major business problems.

Second, the question is determined based on a 4-level scale, including: (i) No obstacles; (ii) Minor obstacles; (iii) Major obstacles; and (iv) Very severe obstacles. In analyzing the data, we removed responses that were not within this scale, for an example, with responses such as "Don't know" and "Does not apply."

We now turn our attention to link each of the five factors included in our tax evasion index into relevant questions obtained from the World Bank Enterprises Survey:

(a) Tax and social security could be represented in assessing the tax rates (Question j30a). The attitude on the tax rates, in general, shows whether a firm is trying to balance the costs and benefits in 
paying tax. If the taxes are excessively high when the business environment is underdeveloped, tax evasion is likely to occur.

(b) With respect to regulations, obtaining business licenses and permits (Question j30c) is always the beginning of any obstacles faced by firms. Consequently, firms' managers tend to hide their incomes to avoid paying appropriate taxes. This variable appears to be appropriate as a proxy for firms in assessing regulations.

(c) Electricity is one of the major goods which is an important input to the operations of firms. In the emerging markets, governments often take control of electricity production, transmission and distribution of energy to firms and households. Electricity also plays a significant role in firms' operations. Facing obstacles in accessing electricity causes a significant reduction in firms' benefits and as such and encourages a tendency to avoid taxes. As such, we consider that obstacles to obtaining electricity (Question c30a) would be able to represent the public sector services.

(d) When discussing the quality of institutions, political instability is used as an appropriate measure (Question j30e). A high level of political instability causes risk and uncertainty in the business environment and reduces a government's ability to manage the economy, including tax collection. Such risks and uncertainty faced by firms would make them more likely to hide their profits to avoid the payment of taxes.

(e) Obstacles in corruption (Question j30f) are used as a proxy for tax compliance. High level of corruption in an emerging market is the signal that indicates bad economic governance, thereby creating opportunities for firms to evade tax. Using data for the ASEAN countries, Vo et al. (2015) concluded the positive impacts of corruption on the shadow economy. The authors also considered that the effect of corruption to the shadow economy is at a higher degree in comparison with the effect from shadow economy to corruption.

The new TEI in this paper is constructed, as in Table 1 below, by calculating an equally weighted average (mean) of the above five indicators which represent the five main sources of effects to tax evasion by firms.

Table 1. Data for a construction of the tax evasion index.

\begin{tabular}{|c|c|c|c|}
\hline Variables & Definition/Calculation & Sources & Level \\
\hline $\begin{array}{l}\text { Problem with Tax and } \\
\text { social security contribution } \\
\text { burdens }\end{array}$ & $\begin{array}{l}\text { Question j30a: Assessment of tax rates as No } \\
\text { Obstacle, a Minor Obstacle, a Major Obstacle or a } \\
\text { Very Severe Obstacle to the current operations of this } \\
\text { establishment. }\end{array}$ & $\begin{array}{l}\text { World Bank Private } \\
\text { Enterprise Survey }\end{array}$ & Firm \\
\hline Problem with regulations & $\begin{array}{l}\text { Question j30c: Assessment of business licensing and } \\
\text { permits as No Obstacle, a Minor Obstacle, a Major } \\
\text { Obstacle or a Very Severe Obstacle to the current } \\
\text { operations of this establishment. }\end{array}$ & $\begin{array}{l}\text { World Bank Private } \\
\text { Enterprise Survey }\end{array}$ & Firm \\
\hline $\begin{array}{l}\text { Problem with public sector } \\
\text { services }\end{array}$ & $\begin{array}{l}\text { Question c30a: Assessment of electricity as No } \\
\text { Obstacle, a Minor Obstacle, a Major Obstacle or a } \\
\text { Very Severe Obstacle to the current operations of this } \\
\text { establishment. }\end{array}$ & $\begin{array}{l}\text { World Bank Private } \\
\text { Enterprise Survey }\end{array}$ & Firm \\
\hline $\begin{array}{l}\text { Problem with quality of } \\
\text { institutions }\end{array}$ & $\begin{array}{l}\text { Question J30e: Assessment of political instability as } \\
\text { No Obstacle, a Minor Obstacle, a Major Obstacle or a } \\
\text { Very Severe Obstacle to the current operations of this } \\
\text { establishment. }\end{array}$ & $\begin{array}{l}\text { World Bank Private } \\
\text { Enterprise Survey }\end{array}$ & Firm \\
\hline $\begin{array}{l}\text { Problem with tax } \\
\text { compliance }\end{array}$ & $\begin{array}{c}\text { Question j30f: Assessment of corruption as No } \\
\text { Obstacle, a Minor Obstacle, a Major Obstacle or a } \\
\text { Very Severe Obstacle to the current operations of this } \\
\text { establishment. }\end{array}$ & $\begin{array}{l}\text { World Bank Private } \\
\text { Enterprise Survey }\end{array}$ & Firm \\
\hline Tax evasion index (TEI) & $\begin{array}{l}\text { Combining five above factors in an equally average: } \\
\text { sum answers of five questions/ maximum points. }\end{array}$ & Authors' calculations & Firm \\
\hline
\end{tabular}




\subsection{A Tax Evasion Index across Emerging and Developing Countries}

Once the five key components of the tax evasion index have been identified as previously discussed, without prior perception of the importance of each factor, we consider that equally weighted average of these components appear to be appropriate. On this basis, the tax evasion index across developing and emerging markets is presented in Table 2.

Table 2. Tax Evasion Index (TEI) across emerging market, 2006-2017 period.

\begin{tabular}{|c|c|c|c|c|c|c|c|c|}
\hline No. & Country & $\begin{array}{c}\text { TEI } \\
\text { (mean) }\end{array}$ & No. & Country & $\begin{array}{c}\text { TEI } \\
\text { (mean) }\end{array}$ & No. & Country & $\begin{array}{c}\text { TEI } \\
\text { (mean) }\end{array}$ \\
\hline 1 & Afghanistan & 0.7109 & 39 & Georgia & 0.6841 & 77 & Nigeria & 0.5511 \\
\hline 2 & Albania & 0.6337 & 40 & Ghana & 0.5689 & 78 & Pakistan & 0.6789 \\
\hline 3 & Angola & 0.6808 & 41 & Grenada & 0.5091 & 79 & Panama & 0.5064 \\
\hline 4 & Armenia & 0.6176 & 42 & Guatemala & 0.6467 & 80 & Paraguay & 0.6101 \\
\hline 5 & Azerbaijan & 0.5700 & 43 & Guinea & 0.6724 & 81 & Peru & 0.6058 \\
\hline 6 & Bangladesh & 0.6188 & 44 & $\begin{array}{c}\text { Guinea } \\
\text { Bissau }\end{array}$ & 0.6627 & 82 & Philippines & 0.5154 \\
\hline 7 & Belarus & 0.6253 & 45 & Guyana & 0.6246 & 83 & Romania & 0.6820 \\
\hline 8 & Belize & 0.5743 & 46 & Honduras & 0.6128 & 84 & Rwanda & 0.6244 \\
\hline 9 & Benin & 0.6689 & 47 & India & 0.5753 & 85 & Samoa & 0.5309 \\
\hline 10 & Bhutan & 0.5182 & 48 & Indonesia & 0.5429 & 86 & Senegal & 0.5397 \\
\hline 11 & Bolivia & 0.6392 & 49 & Iraq & 0.7432 & 87 & Serbia & 0.5809 \\
\hline 12 & Bosnia and Herzegovina & 0.6302 & 50 & Jamaica & 0.6034 & 88 & $\begin{array}{l}\text { Sierra } \\
\text { Leone }\end{array}$ & 0.5738 \\
\hline 13 & Botswana & 0.5386 & 51 & Jordan & 0.5408 & 89 & $\begin{array}{l}\text { South } \\
\text { Africa }\end{array}$ & 0.5441 \\
\hline 14 & Brazil & 0.7539 & 52 & Kazakhstan & 0.6255 & 90 & $\begin{array}{l}\text { South } \\
\text { Sudan }\end{array}$ & 0.6472 \\
\hline 15 & Bulgaria & 0.5949 & 53 & Kenya & 0.5743 & 91 & Sri Lanka & 0.5372 \\
\hline 16 & Burkina Faso & 0.6685 & 54 & Kosovo & 0.6324 & 92 & $\begin{array}{l}\text { St. Lucia } \\
\text { St. }\end{array}$ & 0.6306 \\
\hline 17 & Burundi & 0.6320 & 55 & $\begin{array}{c}\text { Kyrgyz } \\
\text { Republic }\end{array}$ & 0.6717 & 93 & $\begin{array}{l}\text { Vincent } \\
\text { and } \\
\text { Grenadines }\end{array}$ & 0.5154 \\
\hline 18 & Cameroon & 0.6377 & 56 & Lao PDR & 0.3750 & 94 & Sudan & 0.6337 \\
\hline 19 & Cape Verde & 0.6141 & 57 & Lebanon & 0.6972 & 95 & Suriname & 0.5724 \\
\hline 20 & Central African Republic & 0.6408 & 58 & Lesotho & 0.5990 & 96 & Swaziland & 0.6185 \\
\hline 21 & Chad & 0.7080 & 59 & Liberia & 0.6372 & 97 & Tajikistan & 0.7218 \\
\hline 22 & China & 0.3315 & 60 & Madagascar & 0.6297 & 98 & Tanzania & 0.6486 \\
\hline 23 & Colombia & 0.6093 & 61 & Malawi & 0.5505 & 99 & $\begin{array}{l}\text { Timor } \\
\text { Leste }\end{array}$ & 0.7333 \\
\hline 24 & Congo Republic & 0.7285 & 62 & Mali & 0.5601 & 100 & Togo & 0.7128 \\
\hline 25 & Costa Rica & 0.6339 & 63 & Mauritania & 0.6044 & 101 & Tonga & 0.4720 \\
\hline 26 & Côte d'Ivoire & 0.7043 & 64 & Mauritius & 0.6556 & 102 & Tunisia & 0.5769 \\
\hline 27 & Djibouti & 0.6011 & 65 & Mexico & 0.6571 & 103 & Turkey & 0.6178 \\
\hline 28 & Dominica & 0.3700 & 66 & Micronesia & 0.5167 & 104 & Uganda & 0.5672 \\
\hline 29 & Dominican Republic & 0.6413 & 67 & Moldova & 0.6900 & 105 & Ukraine & 0.6922 \\
\hline 30 & DR Congo & 0.6552 & 68 & Mongolia & 0.5645 & 106 & Uzbekistan & 0.5691 \\
\hline 31 & Ecuador & 0.6496 & 69 & Montenegro & 0.5056 & 107 & Vanuatu & 0.5693 \\
\hline 32 & Egypt & 0.6687 & 70 & Morocco & 0.6572 & 108 & $\begin{array}{l}\text { Vietnam } \\
\text { West }\end{array}$ & 0.4479 \\
\hline 33 & El Salvador & 0.6365 & 71 & Mozambique & 0.5527 & 109 & $\begin{array}{c}\text { Bank and } \\
\text { Gaza }\end{array}$ & 0.6657 \\
\hline 34 & Eritrea & 0.2500 & 72 & Myanmar & 0.5500 & 110 & Yemen & 0.7262 \\
\hline 35 & Ethiopia & 0.5161 & 73 & Namibia & 0.5136 & 111 & Zambia & 0.5135 \\
\hline 36 & Fiji & 0.5875 & 74 & Nepal & 0.6576 & 112 & Zimbabwe & 0.5816 \\
\hline 37 & Gabon & 0.5250 & 75 & Nicaragua & 0.6500 & & & \\
\hline 38 & Gambia & 0.6875 & 76 & Niger & 0.7128 & & & \\
\hline
\end{tabular}


Table 2 shows that the average tax evasion index (TEI) for emerging markets is 0.62 and that it varies within a range $(0.25,0.75)$. Vietnam has a TEI of 0.4479 , which is considered to be relatively high compared with other emerging countries in the sample.

\section{Effects of Information Sharing and Bank Penetration on Tax Evasion in Emerging Markets}

\subsection{Methodology}

In order to measure the effects of financial developments on tax evasion, we begin with the simple model of Beck et al. (2014). The model represents the financial development factors as descriptive variables to explain unidirectional tax evasion, together with appropriate control variables at both the firm and market levels:

$$
T_{i j k}=\alpha F_{i}+\beta C_{i}+\gamma B_{j}+\theta_{k}+\varepsilon_{i j k}
$$

where $T_{i j k}$ represents the tax evasion ratio for emerging market $i$, firm $j$ and industry $k$; $F_{i}$ is the vector of financial sector indicators, including information sharing and branch penetration variables; $C_{i}$ and $B_{j}$ are groups of control variables ${ }^{1}$ for the emerging market and firm levels, respectively; $\theta_{k}$ is a group of 15 industry dummies; and $\varepsilon_{i j k}$ represents the random error terms for $i, j$ and $k$. The model specification is intended to avoid the possible problem of endogeneity that can arise in panel data studies.

The inclusion of industry dummies is both reasonable and necessary. Due to the differences in the business environment and law, different industries would be expected to exhibit different tax evasion patterns. The dummy variables allow to separate analyses between the industries. The lists of industries, variables in relation to tax evasion, the financial sector and location and firm size, all of which relate to the questions that were discussed above, as well as control variables, are presented in Tables $3-5$ below. The yearly dummies are used to control the within-market differences caused by global trends. Because the tax evasion index (TEI) is a ratio, a positive fraction, the Tobit regression approach with a lower limit of 0 and an upper limit of 1 will be used for the empirical analysis.

Table 3. Financial sector.

\begin{tabular}{|c|c|c|c|}
\hline Variables & Definition/Calculation & Sources & Level \\
\hline Information sharing & $\begin{array}{l}\text { The dummy variable equals } 1 \text { if an information } \\
\text { sharing agency (public credit registry or private } \\
\text { credit bureau) operates in the country (or } \\
\text { emerging market), zero otherwise. }\end{array}$ & $\begin{array}{l}\text { World Bank } \\
\text { "Doing Business" } \\
\text { data base }\end{array}$ & Country \\
\hline $\begin{array}{l}\text { Depth of information } \\
\text { sharing }\end{array}$ & $\begin{array}{c}\text { "Depth of credit information sharing" indicator, } \\
\text { range from 0-6 }\end{array}$ & $\begin{array}{l}\text { World Bank } \\
\text { "Doing Business" } \\
\text { data base }\end{array}$ & Country \\
\hline $\begin{array}{l}\text { Demographic bank } \\
\text { penetration }\end{array}$ & $\begin{array}{c}\text { Number of commercial bank branches per } \\
100.000 \text { adults (coded FB. CBK. BRCH. P5 from } \\
\text { the World Banks Indicator database) }\end{array}$ & $\begin{array}{l}\text { World Bank World } \\
\text { Development } \\
\text { Indicators }\end{array}$ & Country \\
\hline $\begin{array}{l}\text { Geographic bank } \\
\text { penetration }\end{array}$ & $\begin{array}{c}\text { Number of commercial bank branches per } \\
10.000 \text { square km-calculated by: (demographic } \\
\text { bank penetration * total population/100,000) * } \\
10,000 / \text { total area }\end{array}$ & $\begin{array}{l}\text { World Bank World } \\
\text { Development } \\
\text { Indicators }\end{array}$ & Country \\
\hline
\end{tabular}

1 Capital flows may be an important control variable for future studies (for details, see Feldstein (1994); Fratzscher (2012); and Marfatia (2016)). 
Table 4. Location and firm size.

\begin{tabular}{cccc}
\hline Variables & Definition/Calculation & Sources & Level \\
\hline Small city & $\begin{array}{c}\text { Question a3: To be equal 1 if a city has fewer than } \\
\text { 250,000 residents in population (including category 4 } \\
\text { and 5 of the answer), otherwise 0. }\end{array}$ & $\begin{array}{c}\text { World Bank Private } \\
\text { Enterprise Survey }\end{array}$ & Firm \\
\hline Capital city & $\begin{array}{c}\text { Question a3: To be equal 1 if a city is a capital city } \\
\text { (including category 1 of the answer), otherwise 0. }\end{array}$ & $\begin{array}{c}\text { World Bank Private } \\
\text { Enterprise Survey }\end{array}$ & Firm \\
\hline Small firm & $\begin{array}{l}\text { Question a6: Size, firms are categorized by number of } \\
\text { employees. Small firms have from 5 to 19 employees. }\end{array}$ & $\begin{array}{c}\text { World Bank Private } \\
\text { Enterprise Survey }\end{array}$ & Firm \\
\hline Large firm & $\begin{array}{l}\text { Question a6: Size, firms are categorized by number } \\
\text { of employees. Large firms have over 100 employees. }\end{array}$ & $\begin{array}{c}\text { World Bank Private } \\
\text { Enterprise Survey }\end{array}$ & Firm \\
\hline
\end{tabular}

Table 5. Control variables.

\begin{tabular}{cccc}
\hline Variables & Definition/Calculation & Sources & Level \\
\hline Log of GDP per capita & A natural log of GDP per capita. & $\begin{array}{c}\text { World Bank World } \\
\text { Development } \\
\text { Indicators }\end{array}$ & Country \\
\hline Log of firm age & $\begin{array}{c}\text { Question b5: In what year did this establishment begin } \\
\text { operations in this country (or emerging market)? }\end{array}$ & $\begin{array}{c}\text { World Bank Private } \\
\text { Enterprise Survey }\end{array}$ & Firm \\
\hline $\begin{array}{c}\text { Log of manager's } \\
\text { experience level }\end{array}$ & $\begin{array}{c}\text { Question b7: How many years of experience working in } \\
\text { this sector does the top manager have? }\end{array}$ & $\begin{array}{c}\text { World Bank Private } \\
\text { Enterprise Survey }\end{array}$ & Firm \\
\hline
\end{tabular}

In this paper, an emphasis is based on marginal effects rather than on coefficients in order to assess the economic influences. Robust Newey-West HAC standard errors are reported to avoid potential serial correlation and heteroscedasticity. In order to assess the impacts of firm size and location on the relationship between tax evasion and financial development variables, interaction terms are included in the non-nested Equations (2) and (3), as follows:

$$
\begin{gathered}
T_{i j k}=\alpha F_{i}+\tau_{1} F_{i} \times \text { Size }_{j}+\beta C_{i}+\gamma B_{j}+\theta_{k}+\varepsilon_{i j k} \\
T_{i j k}=\alpha F_{i}+\tau_{2} F_{i} \times \text { Location }_{j}+\beta C_{i}+\gamma B_{j}+\theta_{k}+\varepsilon_{i j k}
\end{gathered}
$$

where: Size $_{j}$ is the vector of firm $j^{\prime}$ 's size, including small firm and large firm dummies, as compared with mid-size firms; and Location $j$ is the vector of firm $j$ 's location, including capital city and small city dummies, as compared with mid-sized cities. ${ }^{2}$

\subsection{Data}

The standardized data from the World Bank Enterprises Survey from 2006-2017 is used in the empirical analysis. Emerging markets are selected based on the definition of the World Bank to provide a data set of 112 emerging markets, with more than 29 thousand observations worldwide. Information sharing variables are retrieved from the World Bank Doing Business data base, while bank penetration variables are collected from the World Bank Development Indicators data. Data for other variables have been collected and summarized from the three different sources as mentioned above.

The definition of emerging markets by the World Bank means countries that are classified as low- or middle-income. Low-income countries have income per capita lower than or equal to $\$ 1045$. Middle-income countries consist of two sub-groups which are lower-middle-income (income per capita from $\$ 1046$ to $\$ 4125$ ) and upper-middle-income (income per capita from $\$ 4126$ to $\$ 12,735$ ).

2 Different methods can be considered in the future (for details, see Cekin et al. (2019); Marfatia et al. (2017); and Okunade and Karakus (2001)). 
For Information sharing, two methods of measurement are adopted, both of which are from the World Bank Doing Business data. Specifically, since 2013, the Doing Business data base has changed the underlying method and added two features, making depth of information sharing index range from 0 to 8 . However, in order to allow comparisons over time, in this paper, we use the former index that ranges from 0 to 6 .

A more detailed indicator for information sharing which ranges from zero to six, depending on a number of characteristics that a financial system in an emerging market has from a set of the following six features:

(i) both positive and negative credit information are distributed;

(ii) data on both firms and individual borrowers are distributed;

(iii) data from retailers, trade creditors or utilities, as well as from financial institutions, are distributed;

(iv) more than two years of historical data are distributed;

(v) data are collected on all loans in value above 1 per cent of income per capita; and

(vi) laws provide borrowers the right to inspect their own data. A higher value of the second measurement represents a deeper information sharing status, as well as a more transparent credit environment.

For bank penetration, the paper uses two measures, namely "geographic bank penetration" and "demographic bank penetration," both of which originate from the World Bank World Development Indicators data. The demographic bank penetration, which describes the number of commercial bank branches per 100.000 adults, is collected from the data:

$$
\begin{gathered}
\text { Geographic bank penetration }= \\
\frac{(\text { demographic bank penetration } \times \text { total population })}{100,000} \times \frac{10,000}{\text { total area }}
\end{gathered}
$$

The meaning of the above estimated penetration measure represents the number of commercial bank branches per 10,000 square kilometers for geographic bank penetration. On the right-hand side of the equation, the first fraction illustrates the total number of commercial bank branches in an emerging market, while the second fraction modifies the measure to reflect a "per 10,000 square kilometers" indicator.

The paper also includes the size of enterprises, the firm locations to be sub indicators, to accommodate the second hypothesis and answer the second research question. "Firm size" covers two categories, namely small firm sizes and large firm sizes. Two different dummy variables are used in which the small-sized firm variable is proxied as 1 if a firm has from 5 to 19 employees, while the large-sized firm variable considers firms over 100 employees. "Firm's location" indicators also include capital, which refers to firms located in a capital city and small city, which consists of firms in cities with fewer than 250,000 residents in the population.

The middle-sized firms and cities are the omitted categories. In addition, we add "firm age," for which the natural logarithms of total operating years of a firm until 2017 and the natural logarithm of "GDP per capita" to cover the "experience level of top managers." In order to control the economic trend over time, the paper uses yearly dummies. Tables $3-5$ summarize all the variables together with their definitions and data sources.

\subsection{Empirical Results and Discussions}

\subsubsection{Effects of Information Sharing and Bank Penetration on Tax Evasion}

A set of five regressions is conducted to respond to the first research question, which is: "Do higher information sharing level and wider bank penetration help to reduce tax evasion in emerging markets?"

The Tobit regression results in Table 6 examine the effects of information sharing and bank penetration on tax evasion. Findings from Table 6 indicate that information sharing, including "depth 
of info sharing" and "info sharing," significantly and negatively affect tax evasion from firms in emerging markets. Based on the marginal effects, the existence of a public or private credit bureau and a deep level of information sharing will reduce the probability of tax evasion by firms, regardless of the firm size and location.

Table 6. Effects of information sharing and bank penetration on tax evasion.

\begin{tabular}{|c|c|c|c|c|c|}
\hline & (1) & (2) & (3) & (4) & (5) \\
\hline Variables & \multicolumn{5}{|c|}{ Tobit Regressions } \\
\hline \multirow[t]{2}{*}{ Depth of info sharing } & $-0.00248^{* * *}$ & - & - & - & $-0.00316^{* * *}$ \\
\hline & $(0.000471)$ & - & - & - & $(0.000492)$ \\
\hline \multirow[t]{2}{*}{ Info sharing } & & $-0.0363^{* * *}$ & - & - & - \\
\hline & - & $(0.00307)$ & - & - & - \\
\hline \multirow[t]{2}{*}{ Demographic bank penetration } & - & - & $-0.000247^{* * *}$ & - & - \\
\hline & - & - & $\left(7.55 \times 10^{-5}\right)$ & - & - \\
\hline \multirow[t]{2}{*}{ Geographic bank penetration } & - & - & - & $-1.63 \times 10^{-5 * * *}$ & $-1.18 \times 10^{-5} * *$ \\
\hline & - & - & - & $\left(4.00 \times 10^{-6}\right)$ & $\left(5.77 \times 10^{-6}\right)$ \\
\hline Small city & $-0.0119 * * *$ & $-0.00725^{* * *}$ & $\begin{array}{l}-0.00441 \\
(0.00272)\end{array}$ & -0.00452 & $-0.0101^{* * *}$ \\
\hline \multirow{2}{*}{ Capital city } & $0.0196^{* * *}$ & $0.0239 * * *$ & $0.0261 * * *$ & $0.0248^{* * *}$ & $0.0204^{* * *}$ \\
\hline & $(0.00345)$ & $(0.00331)$ & $(0.00332)$ & $(0.00332)$ & $(0.00347)$ \\
\hline \multirow[t]{2}{*}{ Ln (GDP per capital) } & $-0.00256^{* * *}$ & $-0.00257^{* * *}$ & $-0.00239^{* * *}$ & $-0.00115^{* *}$ & $-0.000995 *$ \\
\hline & $(0.000481)$ & $(0.000441)$ & $(0.000455)$ & $(0.000472)$ & $(0.000513)$ \\
\hline \multirow[t]{2}{*}{ Ln (Firm age) } & $-0.00606^{* * *}$ & -0.000245 & -0.00189 & 0.000108 & $-0.00396^{* * *}$ \\
\hline & $(0.00149)$ & $(0.00142)$ & $(0.00142)$ & $(0.00145)$ & $(0.00153)$ \\
\hline \multirow{2}{*}{ Ln (Top manager's experience) } & $0.00976^{* * *}$ & $0.0132^{* * *}$ & $0.0124 * * *$ & $0.0132 * * *$ & $0.0115^{* * *}$ \\
\hline & $(0.00153)$ & $(0.00139)$ & $(0.00140)$ & $(0.00141)$ & $(0.00158)$ \\
\hline Observations & 22,904 & 28,853 & 28,261 & 27,803 & 21,991 \\
\hline
\end{tabular}

Note: Robust standard errors in parentheses; ${ }^{* * *},{ }^{* *}$ and ${ }^{*}$ denote statistical significance at the $1 \%, 5 \%$ and $10 \%$ levels, respectively.

A higher level of information sharing indicates a more transparent financial environment. Business owners have greater incentives as every mistake in attempting to evade taxes could lead to bad credit positioning, which would negatively and severely affect the ability of obtaining lines of credit for firms in the future.

The effects of bank penetration through "demographic bank penetration" and "geographic bank penetration" on tax evasion are also statistically significant and negative at the 1 per cent level. This study finds that a higher level of bank penetration will reduce tax evasion level by firms.

\subsubsection{Firm Size and Location Influences}

Table 7 examines the effects of firm size on the effect of information sharing and bank penetration on tax evasion. The estimated coefficients show a consistent pattern across the three models. In general, information sharing and bank penetration tend to provide higher effects on larger firms than on medium-sized firms. 
Table 7. Information sharing and bank penetration on tax evasion with the focus on firm's size.

\begin{tabular}{|c|c|c|c|}
\hline & (1) & (2) & (3) \\
\hline Variables & \multicolumn{3}{|c|}{ Tobit Regressions } \\
\hline Depth of info sharing & $\begin{array}{c}-0.00223 * * * \\
(0.000602)\end{array}$ & & \\
\hline Depth of info sharing $x$ Small firm & $\begin{array}{c}0.000749 \\
(0.000635)\end{array}$ & & \\
\hline Depth of info sharing $x$ Large firm & $\begin{array}{c}-0.00323 * * * \\
(0.000823)\end{array}$ & & \\
\hline Demographic bank penetration & & $\begin{array}{c}-0.000175^{*} \\
\left(9.67 \times 10^{-5}\right)\end{array}$ & \\
\hline Demographic bank penetration $x$ Small firm & & $\begin{array}{c}6.46 \times 10^{-5} \\
(0.000118)\end{array}$ & \\
\hline Demographic bank penetration $x$ Large firm & & $\begin{array}{c}-0.000439 * * * \\
(0.000137)\end{array}$ & \\
\hline Geographic bank & & & $\begin{array}{c}-9.78 \times 10^{-6 * *} \\
\left(4.87 \times 10^{-6}\right)\end{array}$ \\
\hline Geographic bank x Small firm & & & $\begin{array}{l}-5.30 \times 10^{-6} \\
\left(6.51 \times 10^{-6}\right)\end{array}$ \\
\hline Geographic bank $x$ Large firm & & & $\begin{array}{c}-2.48 \times 10^{-5 * * *} \\
\left(7.43 \times 10^{-6}\right)\end{array}$ \\
\hline Small city & $\begin{array}{c}-0.0117 \text { *** } \\
(0.00286)\end{array}$ & $\begin{array}{c}-0.00465 * \\
(0.00272)\end{array}$ & $\begin{array}{l}-0.00438 \\
(0.00279)\end{array}$ \\
\hline Capital city & $\begin{array}{l}0.0200^{* * *} \\
(0.00345)\end{array}$ & $\begin{array}{l}0.0264^{* * *} \\
(0.00332)\end{array}$ & $\begin{array}{l}0.0250^{* * *} \\
(0.00332)\end{array}$ \\
\hline Ln (GDP per capita) & $\begin{array}{c}-0.00257^{* * *} \\
(0.000480)\end{array}$ & $\begin{array}{c}-0.00241^{* * * *} \\
(0.000454)\end{array}$ & $\begin{array}{c}-0.00114^{* *} \\
(0.000472)\end{array}$ \\
\hline Ln (Firm age) & $\begin{array}{c}-0.00529^{* * *} \\
(0.00150)\end{array}$ & $\begin{array}{l}-0.00143 \\
(0.00143)\end{array}$ & $\begin{array}{l}0.000249 \\
(0.00145)\end{array}$ \\
\hline Ln (Top manager's experience) & $\begin{array}{c}0.00993^{* * * *} \\
(0.00153)\end{array}$ & $\begin{array}{l}0.0125^{* * *} \\
(0.00140)\end{array}$ & $\begin{array}{l}0.0132 * * * \\
(0.00142)\end{array}$ \\
\hline Observations & 22,904 & 28,261 & 27,803 \\
\hline
\end{tabular}

Note: Robust standard errors in parentheses; ${ }^{* * *},{ }^{* *}$ and ${ }^{*}$ denote statistical significance at the $1 \%, 5 \%$ and $10 \%$ levels, respectively.

For similar reasons, a different relationship is expected for the effect of information sharing and bank penetration on the degree of tax evasion across firms at different locations. The effects of location on the relationship between financial development and tax evasion are presented in Table 8 . The empirical findings indicate that locating in small cities and towns seems to weaken the effect of information sharing and bank penetration on the degree of tax evasion.

In small cities, there is a limited effect of information sharing and bank penetration on the tax decisions of firms. The distance to the economic center may reduce the strength of regulations as it can be difficult for tax officers to visit firms on a frequent basis. However, this effect is positive and insignificant when demographic bank penetration is used. The results are not especially consistent across the three regressions models but could still be described as an overall pattern. In summary, information sharing and bank penetration are found to provide higher effects on tax evasion for large firms and lower effects for firms that are located in small cities and towns. 
Table 8. Information sharing and bank penetration on tax evasion with the focus on firm's location.

\begin{tabular}{|c|c|c|c|}
\hline & (1) & (2) & (3) \\
\hline Variables & \multicolumn{3}{|c|}{ Tobit Regressions } \\
\hline Depth of info sharing & $\begin{array}{c}-0.00332 * * * \\
(0.000618)\end{array}$ & & \\
\hline Depth of info sharing $x$ Capital city & $\begin{array}{l}0.000749 \\
(0.00118)\end{array}$ & & \\
\hline Depth of info sharing $x$ Small city & $\begin{array}{c}0.00317^{* * *} \\
(0.00111)\end{array}$ & & \\
\hline Demographic bank penetration & & $\begin{array}{l}-0.000240 * * \\
(0.000115)\end{array}$ & \\
\hline $\begin{array}{l}\text { Demographic bank penetration x Capital } \\
\text { city }\end{array}$ & & 0.000210 & \\
\hline & & $(0.000172)$ & \\
\hline Demographic bank penetration $x$ Small city & & $\begin{array}{l}-0.000236 \\
(0.000175)\end{array}$ & \\
\hline Geographic bank penetration & & & $\begin{array}{c}-2.91 \times 10^{-5} \text { **** } \\
\left(4.87 \times 10^{-6}\right)\end{array}$ \\
\hline Geographic bank penetration $x$ Capital city & & & $\begin{array}{c}2.04 \times 10^{-5} \\
\left(1.46 \times 10^{-5}\right)\end{array}$ \\
\hline Geographic bank penetration $x$ Small city & & & $\begin{array}{c}3.97 \times 10^{-5} * * * \\
\left(8.58 \times 10^{-6}\right)\end{array}$ \\
\hline Small city & $\begin{array}{c}-0.0217 * * * \\
(0.00441)\end{array}$ & $\begin{array}{c}-0.000445 \\
(0.00365)\end{array}$ & $\begin{array}{c}-0.0161^{* * *} \\
(0.00388)\end{array}$ \\
\hline Capital city & $\begin{array}{l}0.0173^{* * *} \\
(0.00525)\end{array}$ & $\begin{array}{l}0.0217^{* * *} \\
(0.00432)\end{array}$ & $\begin{array}{l}0.0209^{* * *} \\
(0.00384)\end{array}$ \\
\hline Ln(GDP per capita) & $\begin{array}{c}-0.00254^{* * *} \\
(0.000482)\end{array}$ & $\begin{array}{l}-0.00233^{* * *} \\
(0.000456)\end{array}$ & $\begin{array}{l}-0.00140^{* * *} \\
(0.000476)\end{array}$ \\
\hline Ln(Firm age) & $\begin{array}{c}-0.00609 * * * \\
(0.00149)\end{array}$ & $\begin{array}{l}-0.00186 \\
(0.00142)\end{array}$ & $\begin{array}{l}0.000241 \\
(0.00145)\end{array}$ \\
\hline Ln(Top manager's experience) & $\begin{array}{c}0.00972^{* * *} \\
(0.00152)\end{array}$ & $\begin{array}{l}0.0124^{* * *} \\
(0.00140)\end{array}$ & $\begin{array}{l}0.0130 * * * \\
(0.00141)\end{array}$ \\
\hline Observations & 22,904 & 28,261 & 27,803 \\
\hline
\end{tabular}

Note: Robust standard errors in parentheses; ${ }^{* * *}$ and ${ }^{* *}$ denote statistical significance at the $1 \%$ and $5 \%$ levels, respectively.

\section{Conclusions and Policy Implications}

Tax evasion has been a major concern for developing and emerging markets for an extended period. The issue has attracted great attention from policymakers, practitioners and academics. In addition, the importance of information share and bank penetration has largely been ignored in the literature for emerging markets. This paper is conducted to provide a comprehensive analysis of tax evasion in emerging markets by exploring the following objectives.

A new tax evasion index (TEI) is developed using data from the standardized World Bank Enterprises Survey 2006-2017. Doing so provides a basis for a comparison of different levels of tax evasion across emerging markets. Second, the paper explores the importance of information sharing and bank penetration on tax evasion in emerging markets. Third, the paper also investigates the above relationship of information sharing and bank penetration on tax evasion when firm size and firm location are taken into account.

The key findings of the paper can be summarized as follows:

(1) On the basis of the literature review, the influential factors to develop the new tax evasion index (TEI) include: (i) tax and social security contribution burdens; (ii) regulations; (iii) public sector services; (iv) quality of institutions; and (v) tax compliance using equal weights. The new TEI presents a range of tax evasion degree from 0.25 to 0.7.539. Among these emerging markets, 
Brazil has the highest TEI of 0.7539 , while Eritrea had the lowest TEI of 0.25 . Corruption appears to contribute substantially to the degree of tax evasion from firms in the emerging markets.

(2) A model developed by Beck et al. (2014) was used to investigate the contribution and importance of information sharing and bank penetration on tax evasion which is proxied by the new TEI. The empirical results showed that higher levels of information sharing and bank penetration reduced tax evasion in emerging markets.

(3) The contribution and importance of information sharing and bank penetration on tax evasion is reconsidered when we take firm size and location into consideration. The empirical results indicated that larger firms were less likely to evade taxes in an environment with strong financial development. Firms located in small regions appeared to evade taxes more often than in medium-sized cities if there was a high level of information sharing or bank penetration. In addition, the characteristics of locating in capital cities or small sizes did not have a significant impact on the effect of information sharing and bank penetration on tax evasion in emerging markets.

Policy implications have emerged on the grounds of these empirical findings. First, governments from emerging markets should be aware of the degree of tax evasion in their countries, so that appropriate policies can be implemented to minimize such occurrence. On this basis, the new tax evasion index can provide a starting point for government considerations. In particular, the index includes various factors which contribute to the degree of tax evasion in the country. The government should take note of these key and fundamental factors. As an example, the paper finds that corruption played an important role in tax evasion in emerging markets.

It was found that information sharing and bank penetration did contribute negatively to the degree of tax evasion in emerging markets. As such, policies targeting information sharing and bank penetration can help to reduce the degree of tax evasion. This empirical result supports the view that a higher level of financial development should be promulgated as an effective method to restrict tax evasion in emerging markets.

It appears that even if there is a high level of information sharing and bank penetration in emerging markets, firms that are located in small cities appeared to evade taxes more often because physical isolation was able to provide greater opportunities for tax evasion. As such, governments in emerging markets should enable tax authorities to increase the number of staff in tax offices in small cities to restrict tax evasion through more frequent random tax inspections.

Author Contributions: Conceptualization, D.H.V., T.M.V. and H.M.N.; Methodology, M.M.; Software, T.M.V.; Validation, D.H.V., H.M.N. and M.M.; Formal Analysis, T.M.V.; Investigation, D.H.V.; Resources, D.H.V. and T.M.V.; Data Curation, T.M.V.; Writing-Original Draft Preparation, T.M.V. and D.H.V.; Writing-Review \& Editing, H.M.N. and M.M.; Visualization, T.M.V.; Supervision, D.H.V.; Project Administration, D.H.V., H.M.N., and M.M. All authors have read and agreed to the published version of the manuscript.

Funding: This research received no external funding.

Acknowledgments: The authors wish to thank two reviewers for very helpful comments and suggestions. For financial support, the first and second authors thank Ho Chi Minh City Open University; the fourth author is grateful to the Australian Research Council and the Ministry of Science and Technology (MOST), Taiwan.

Conflicts of Interest: The authors declare no conflict of interest.

\section{References}

Allingham, Michael, and Angar Sandmo. 1972. Income tax evasion: A theoretical analysis. Journal of Public Economics 1: 323-38. [CrossRef]

Barth, James, Chen Lin, Ping Lin, and Frank Song. 2009. Corruption in bank lending to firms: Cross-country micro evidence on the beneficial role of competition and information sharing. Journal of Financial Economics 91: 361-88. [CrossRef]

Beck, Thorsten, Asli Demirgüç-Kunt, and Vojislaw Maksimovic. 2005. Financial and legal constraints to growth: Does firm size matter? Journal of Finance 60: 137-77. [CrossRef] 
Beck, Thorsten, Asli Demirguc-Kunt, and Maria Peria. 2007. Reaching out: Access to and use of banking services across countries. Journal of Financial Economics 85: 234-66. [CrossRef]

Beck, Thorsten, Asli Demirgüç-Kunt, and Maria Pería. 2011. Bank financing for SMEs: Evidence across countries and bank ownership types. Journal of Financial Services Research 39: 35-54. [CrossRef]

Beck, Thorsten, Chen Lin, and Yue Ma. 2014. Why do firms evade taxes? The role of information sharing and financial sector outreach. Journal of Finance 69: 763-817. [CrossRef]

Brown, Martin, Tullio Jappelli, and Marco Pagano. 2009. Information sharing and credit: Firm-level evidence from transition countries. Journal of Financial Intermediation 18: 151-72. [CrossRef]

Cekin, Semih, Menelik Geremew, and Hardik Marfatia. 2019. Monetary policy co-movement and spillover of shocks among BRICS economies. Applied Economics Letters 26: 1253-63. [CrossRef]

Ela, Melmet. 2013. An assessment on the relationship between informal economy and educational level in Turkey. International Journal of Economics and Financial Issues 3: 910.

Feldstein, Martin. 1994. Tax Policy and International Capital Flows (No. w4851). Berlin/Heidelberg: Springer, vol. 130, pp. 675-97.

Fratzscher, Marcel. 2012. Capital flows, push versus pull factors and the global financial crisis. Journal of International Economics 88: 341-56. [CrossRef]

Frey, Bruno, and Hannelore Weck. 1983a. Bureaucracy and the shadow economy: A macro-approach. In Anatomy of Government Deficiencies. Berlin/Heidelberg: Springer, pp. 89-109.

Frey, Bruno, and Hannelore Weck. 1983b. Estimating the shadow economy: A 'naïve' approach. Oxford Economic Papers 55: 23-44. [CrossRef]

Frey, Bruno, and Hannelore Weck. 1984. The hidden economy as an 'unobserved' variable. European Economic Review 26: 33-53. [CrossRef]

Friedman, Eric, Simon Johnson, Daniel Kaufmann, and Pable Zoido-Lobaton. 2000. Dodging the grabbing hand: The determinants of unofficial activity in 69 countries. Journal of Public Economics 76: 459-93. [CrossRef]

Gellard, Beau, Stefan Mero, and Duc Vo. 2013. Estimating the market value of franking credits: Empirical evidence from Australia. Paper presented at the 2013 Australian Conference of Economists, Perth, Australia, February 5-8.

Graham, John, Si Li, and Jiaping Qiu. 2008. Corporate misreporting and bank loan contracting. Journal of Financial Economics 89: 44-61. [CrossRef]

Houston, Joel, Chen Lin, Ping Lin, and Yue Ma. 2010. Creditor rights, information sharing and bank risk taking. Journal of Financial Economics 96: 485-512. [CrossRef]

Johnson, Simon, Daniel Kaufmann, and Paul Zoido-Lobaton. 1998. Regulatory discretion and the unofficial economy. American Economic Review 88: 387-92.

Johnson, Simon, Daniel Kaufmann, John McMillan, and Christopher Woodruff. 2000. Why do firms hide? Bribes and unofficial activity after communism. Journal of Public Economics 76: 495-520. [CrossRef]

Love, Innesa, and Natalya Mylenko. 2003. Credit Reporting and Financing Constraints. World Bank Policy Research Working Paper WPS 3142. Washington, DC, USA: The World Bank.

Ly, Thinh, and Duc Vo. 2014. Measuring the shadow economy in the ASEAN nations: The MIMIC approach. International Journal of Economics and Finance 6: 139-48.

Marfatia, Henry. 2016. The Role of Push and Pull Factors in Driving Global Capital Flows. Applied Economics Quarterly (formerly: Konjunkturpolitik) 62: 117-46. [CrossRef]

Marfatia, Hardik, Rangan Gupta, and Esin Cakan. 2017. The international REIT's time-varying response to the US monetary policy and macroeconomic surprises. The North American Journal of Economics and Finance 42: 640-53. [CrossRef]

Ministry of Finance of Bulgaria. 2016. The Shadow Economy: How to Measure and Model It. Available online: http://www.minfin.bg/document/9795:4 (accessed on 29 March 2016).

Okunade, Albert, and Mustafa Karakus. 2001. Unit root and cointegration tests: Timeseries versus panel estimates for international health expenditure models. Applied Economics 33: 1131-37. [CrossRef]

Pham, Tien, and Duc Vo. 2014. Any link between unofficial economy and official economy? An empirical evidence for the ASEAN. International Journal of Economics and Finance 6: 97-116.

Rizzi, Dino. 2017. Tax Evasion Indices and Profiles. Public Finance Review 45: 771-91. [CrossRef] 
Schneider, Friedrich, and Andreas Buehn. 2013. Shadow Economies in Highly Developed OECD Countries: What Are the Driving Forces? Working Paper, No. 1317. Linz, Austria: Department of Economics, Johannes Kepler University of Linz.

Schneider, Friedrich, and Dominik Enste. 2000. Shadow economies: Size, causes and consequences. Journal of Economic Literature 38: 77-114. [CrossRef]

Straub, Stephane. 2005. Informal sector: The credit market channel. Journal of Development Economics 78: $299-321$. [CrossRef]

Tran, Dai, and Duc Vo. 2018. Should bankers be concerned with Intellectual capital? A study of the Thai banking sector. Journal of Intellectual Capital 19: 897-914. [CrossRef]

Vo, Duc, Dao Ha, and Thinh Ly. 2015. Shadow Economy and Corruption in the ASEAN: Complement or Substitute? In A New Paradigm for International Business. Singapore: Springer, pp. 151-69.

(C) 2020 by the authors. Licensee MDPI, Basel, Switzerland. This article is an open access article distributed under the terms and conditions of the Creative Commons Attribution (CC BY) license (http://creativecommons.org/licenses/by/4.0/). 